\title{
Kepemimpinan Kaum Minoritas: Analisis Teks Keluaran 1-2
}

\author{
Panca Parulian S \\ Sekolah Tinggi Teologi INTI Bandung \\ Email: limapanca888@gmail.com
}

\begin{abstract}
Leadership always looks at three main aspects: the leader, the follower, and the situation. These three aspects also make leadership theory always tested in new contexts so that experts continue to seek which leadership theory is most effective in specific contexts. This has the consequence of the dominance of research related to leadership in the organizational context, which is also seen in Christian leadership studies in constructing Christian leadership. Analysis of Christian leadership usually focuses on God and one particular character. This article explains that at least three main aspects are needed to examine Christian leadership: theological, leadership process, and reflective. This article offers to read the text in its entirety and pay attention to each of the roles involved. Reading the text of Exodus 1-2 finds the leadership of the minority against the rulers, namely the midwives and Moses: creative disobedience and the death of a vision. Thorough leadership analysis is needed in building Christian leadership.
\end{abstract}

Key Words: Leadership, Christian Leadership, Minorities, Biblical

\begin{abstract}
Abstrak
Kepemimpinan selalu melihat tiga aspek utama: pemimpin, pengikut, dan situasi. Tiga aspek itu juga yang membuat teori kepemimpinan selalu diuji dalam konteks yang selalu baru, sehingga para ahli terus mengupayakan teori kepemimpinan mana yang paling efektif dalam konteks tertentu. Hal itu memberikan konsekuensi dominasi penelitian terkait kepemimpinan dalam konteks organisasi terlihat juga dalam penelitian-penelitian kepemimpinan Kristen dalam mengonstruksi kepemimpinan Kristen. Analisis kepemimpinan Kristen biasanya terfokus pada Allah dan satu tokoh tertentu saja. Artikel ini memberikan pemahaman setidaknya diperlukan tiga aspek utama untuk mengkaji kepemimpinan Kristen: teologis, proses kepemimpinan, dan reflektif. Artikel ini menawarkan untuk membaca teks secara menyeluruh dan memerhatikan setiap peran yang terlibat. Pembacaan teks Keluaran 1-2 menemukan kepemimpinan dari kaum minoritas terhadap penguasa, yakni para bidan-bidan dan Musa: creative disobedience dan the death of vision. Analisis kepemimpinan yang menyeluruh diperlukan dalam membangun kepemimpinan Kristen.
\end{abstract}

Kata-kata Kunci: Kepemimpinan, Kepemimpinan Kristen, Kaum Minoritas, Biblik 


\section{PENDAHULUAN}

Pembahasan

mengenai kepemimpinan sesungguhnya topik yang tidak akan pernah berakhir, karena komponen dasar kepemimpinan yang terdiri dari pemimpin, pengikut, dan situasi selalu berhadapan dengan konteks yang berbeda-beda. Semua aspek kehidupan seperti bisnis, pendidikan, agama, dan politik selalu terkait erat dengan isu kepemimpinan. Berbagai model teori dan praktis sudah dibahas oleh berbagai ahli untuk memberikan kontribusi tentang kepemimpinan yang paling efektif dalam seluruh aspek di atas. Hal itu berlaku juga di dalam teori-teori kepemimpinan dengan perspektif Kristen yang dilihat sebagai kebutuhan dari gereja atau kehidupan bermasyarakat sekarang ini.

Dalam konteks Alkitab artikel ini menambahkan perspektif Fretheim yang secara tidak langsung membahas tentang isu kepemimpinan. Beberapa pemahaman mengenai konstruksi relasional antara Tuhan yang terkandung dalam kitab Keluaran secara lengkap diungkapkan oleh Fretheim. Pertama-tama Fretheim membandingkan beberapa penulis seperti Houtman yang terfokus kepada Godcentered dan menyimpulkan bahwa Tuhanlah yang mengontrol segala sesuatu yang terjadi dalam narasi Keluaran termasuk kepada sesuatu hal yang janggal
(Pharaoh's acts) serta menyimpulkan bahwa setiap pembaca kitab Keluaran perlu sadar bahwa pembebasan Israel bukanlah pekerjaan manusia, tetapi pekerjaan Tuhan; tidak sedikit pun manusia mengambil bagian dalam pembebasan Israel (Terence E. Fretheim, 2014, p. 592). Tidak demikian dengan teks Keluaran 1-2, justru dengan tidak dituliskannya secara langsung peran Allah dalam narasi itu, memberikan kesempatan untuk menganalisis nilai kepemimpinan bukan dengan perspektif teologi God-centered. Justru dengan menggunakan pemahaman itu, artikel ini menemukan kepemimpinan kaum minoritas dalam hal ini bidan-bidan dan Musa dalam menghadapi kekuasaan Raja. Bagaimana menganalisis nilai kepemimpinan dalam teks Keluaran 1-2? Dan bagaimana kepemimpinan kaum minoritas yang ditunjukkan dalam teks ini?

\section{METODE PENELITIAN}

Metode penelitian yang digunakan dalam artikel ini adalah penelitian studi kepustakaan dengan menganalisis deskriptif teks Keluaran 1-2. Alat untuk menganalisis teks tersebut menggunakan sumber utama terkait Kitab Keluaran dari Fretheim. Perangkat-perangkat tafsir dalam ini buku-buku tafsir dan teologi biblika digunakan sebagai alat untuk 
mendeskripsikan tinjauan teologis, yang kemudian direfleksikan untuk melihat nilainilai kepemimpinan.

Proses tafsir yang akan coba ditunjukkan dalam narasi Keluaran membutuhkan perspektif kepemimpinan dan juga perspektif teologis. Untuk itu sebelum proses interpretasi dalam kitab Keluaran 1-2, makalah ini memberikan catatan-catatan kepemimpinan berdasarkan kepemimpinan konteks organisasi dari Northhouse, kepemimpinan dalam konteks teologis dari Clinton dan Cenac. Kemudian, analisis teologi dalam kitab Keluaran dari Fretheim dan beberapa perspektif ahli lainnya. Perspektif ahli tersebut digunakan sebagai alat yang membentuk paradigma yang memberikan perspektif tafsir dalam meneliti kepemimpinan dalam Alkitab. Setelah perspektif itu terbentuk, maka akan lebih mudah untuk melihat narasi dalam Keluaran dengan kaca mata kepemimpinan.

Penelitian mengenai nilai-nilai kepemimpinan dalam Alkitab perlu ditelusuri berdasarkan perspektif kepemimpinan dan teologi yang jelas, sehingga alat tafsir yang digunakan tidak mengurangi kedinamisan dari konteks teks. Sebagaimana kepemimpinan selalu melibatkan tiga komponen utama, yakni pemimpin, pengikut, dan situasi, dengan demikian, penelitian terhadap kepemimpinan dalam narasi Keluaran 1-2 perlu melihat pemisahan yang jelas dari peran, kelompok yang terlibat, dan situasi yang menjadi bagian dalam narasi.

\section{HASIL DAN PEMBAHASAN}

Metode kepemimpinan dalam konteks organisasi sudah secara lengkap dituliskan oleh Northouse, dengan berbagai varian pendekatan dari kepemimpinan yang berorientasi pada sosok pemimpin, sampai kepada pengikut dan situasi (Northouse, 2016). Juga pendekatan-pendekatan dalam mendekati teks Alkitab sudah dianalisis oleh Bekker (Bekker, 2009) dan Clinton yang mengupayakan analisis terhadap seluruh kitab untuk melihat nilai-nilai kepemimpinan (J. Robert Clinton, 1993). Makalah ini akan mencoba mengonstruksi proses kepemimpinan dalam teks Keluaran 1-2 secara terpusat. Hal ini sedikit berbeda dengan Clinton yang menggunakan analisis yang luas, yakni konteks kitab-kitab.

Kedinamisan dari teori-teori kepemimpinan itu sendiri memberikan gambaran yang kompleks untuk menentukan komponen yang paling efektif. Oleh karena itu, daripada melihat keuniversalan indikator suatu kepemimpinan, mengikuti pendapat Northouse, penerimaan teori kepemimpinan sebagai suatu yang kompleks dan dinamis menjadi suatu hal yang dapat diterima. Di dalam konteks organisasi, definisi Northouse di dalam 
memahami kepemimpinan menegaskan bahwa meskipun banyak cara untuk menggagas definisi kepemimpinan tetapi ada berbagai komponen yang pasti teridentifikasi, yaitu: kepemimpinan adalah sebuah proses, pengaruh, terjadi dalam sebuah grup/ kelompok, dan memiliki tujuan. Berdasarkan komponen-komponen tersebut Northouse mendefinisikan kepemimpinan sebagai proses yang di mana individu mempengaruhi kelompok dari tiap-tiap individu untuk mencapai tujuannya (Northouse, 2016, p. 5). Northouse berpendirian bahwa kepemimpinan merupakan sebuah proses; (2) kepemimpinan merupakan sebuah fenomena yang ada dalam interaksi antara pemimpin dan pengikut; dan (3) kepemimpinan berlaku untuk semua orang dan bisa dipelajari (Northouse, 2016, p. 8). Di dalam konteks nilai kepemimpinan dalam Alkitab, Clinton menyimpulkan bahwa di dalam mempelajari kepemimpinan dalam Alkitab, perlu melihat kapan itu terjadi, pemimpin seperti apa yang penting dalam era tersebut, apa fungsi utama daripada mereka, dan seberapa banyak mereka mengerti tujuan Tuhan dan rencananya; They must judges in terms of their own leadership era and not succeeding eras (J. Robert Clinton, 1993, p. 47). Secara spesifik Clinton sudah melihat kemunculan dalam kitab Keluaran di dalam konteks kitab-kitab yang melihat Tuhan memberikan suatu janji untuk membentuk suatu bangsa, untuk itu suatu bangsa membutuhkan seorang pemimpin, tanah, dan sistem-nilai (J. Robert Clinton, 1993, p. 65). Clinton juga mendefinisikan kepemimpinan dalam perspektif Alkitab, $A$ leader is a person with God-given capacity and God-given responsibility to influence a specific group of God's people toward God's purpose (J. Robert Clinton, 1993, p. 163). Sebagai pembanding Cenac melihat secara fenomenologi kemunculan seorang pemimpin dalam Alkitab. Meskipun tidak secara khusus membahas mengenai kitab Keluaran, Cenac memberikan perspektif teologi dalam memahami proses kepemimpinan. Di dalam memahami kemunculan seorang pemimpin Cenac memberikan pemahaman baru tentang pemahaman pemimpin yang dilahirkan atau dilatih, yaitu pemimpin itu muncul/ dimunculkan (Cenac, 2010, p. 126). Cenac mengklaim bahwa karakteristik kemunculan seorang pemimpin itu lebih dinamis daripada yang diungkapkan oleh Clinton's Emergence Leadership. Hal itu diterangkan sebagai berikut.

Dari keterangan di atas menunjukkan bahwa tidak ada perbedaan yang signifikan antara perspektif Alkitab dengan definisi kepemimpinan dalam konteks organisasi. Namun, jika terlalu fokus kepada Godcentered sebagai seorang pemimpin, maka analisis kepemimpinan akan terlalu fokus 
kepada pemusatan Tuhan yang merupakan peran utama, dan tidak memperhatikan keterlibatan agen-agen lain dalam narasi Alkitab. Sebagai contoh, peran utama dalam peristiwa penyelamatan bayi Musa memberikan fokus kepada peran perempuan. Meskipun demikian, konsep God-centered wajar saja, karena beberapa teologi umum mengenai kitab Keluaran selalu terfokus kepada Tuhan. Sebagai contoh Dozeman yang memberikan kerangka teologis dari kitab Keluaran yang terdiri dari dua konstruksi teologi, yaitu: pertama, the character of God's divine power; dan kedua, the nature of divine God's presence in this world (Dozeman, 2010, p. 5).

Sebagai pembanding Fretheim menuliskan pendapat Brueggeman sebagai berikut.

The strategy of the drama depends on the complete obedience and daring of Moses and Aaron ... the critics of liberation theology are not correct in their insistence that the exodus is done by God and not by human initiative. In this and in the following narratives, all that is visible in the ongoing confrontation is human courage and human claims of authority. Behind that human action are certainly the references, claims, and allusions to the power and purpose of Yahweh, but they function primarily to give authorization and legitimacy to the human actors. (Terence E. Fretheim, 2014, p. 593).

Selanjutnya, Fretheim memberikan pemahaman Goldingay yang menggunakan perspektif supernatural yang terkandung dalam 10 tulah yang menyimpulkan bahwa
Tuhanlah yang mengambil Tuhan semua tanpa menggunakan kontribusi manusia (Terence E. Fretheim, 2014, p. 594). Fretheim menilai Childs, While the final form of the text is critical of any effort to divide the text into natural and supernatural elements, Childs seems, finally, to claim that God is the only agent of consequence (Terence E. Fretheim, 2014, p. 595).” Beberapa perspektif teologi yang bisa ditambahkan sebagai pembanding adalah perspektif Von rad dan Coats yang menerangkan tentang peran Musa dan Tuhan yang bersifat timbal balik (David Noel Freedman, 1992, p. 913).

Fretheim menyimpulkan: "Tuhan memilih untuk bekerja dengan dan melalui manusia untuk mencapai tujuan-Nya. Tuhan selalu menggunakan agen dalam bekerja terkait dunia ini (Terence E. Fretheim, 2014, p. 606). Selanjutnya Fretheim menerangkan, "Baik Tuhan maupun agen-agen-Nya memiliki peran yang sangat penting (Terence E. Fretheim, 2014, p. 608). Fretheim memberikan keterangan lebih lanjut bahwa Tuhan menghargai suatu hubungan dan menegaskan bahwa agents of God bukanlah sebuah boneka di tangan Tuhan, karena mereka memiliki kuasa untuk memilih dan mengambil arah yang terbentang dalam kehendak Tuhan (Terence E. Fretheim, 2014, p. 606). Berdasarkan pembahasan di 
atas, konsep dapat disimpulkan definisi kepemimpinan dalam tabel:

Tabel 1 Definisi Kepemimpinan

\begin{tabular}{|l|l|}
\hline Perspektif & Definisi Kepemimpinan \\
\hline Northouse & $\begin{array}{l}\text { Kepemimpinan merupakan } \\
\text { sebuah proses, pengaruh, } \\
\text { terjadi dalam sebuah } \\
\text { grup/kelompok, dan memiliki } \\
\text { tujuan. }\end{array}$ \\
\hline Clinton & $\begin{array}{l}\text { Pemimpin merupakan pribadi } \\
\text { yang diberikan kapasitas oleh } \\
\text { Tuhan dan tanggung jawab } \\
\text { untuk memengaruhi } \\
\text { kelompok tertentu untuk } \\
\text { mencapai tujuan Tuhan }\end{array}$ \\
\hline Fretheim & $\begin{array}{l}\text { Tuhan memilih untuk bekerja } \\
\text { dengan dan melalui manusia. } \\
\text { Agen-Nya diberikan kuasa } \\
\text { dan tanggung jawab untuk } \\
\text { keberlangsungan hubungan }\end{array}$ \\
\hline
\end{tabular}

Konsep-konsep di atas memberikan keterangan bahwa di dalam melihat kepemimpinan Alkitab yang komprehensif perlu melihat proses kepemimpinan yang mencakup pengaruh, tujuan, kemunculan pemimpin, role (peran), interaksi pemimpin-pengikut, dan selalu mencakup kepada interaksi pemimpin-pengikut-dan situasi. Konstruksi dari perspektifperspektif di atas juga memungkinkan penelusuran tindakan-tindakan kepemimpinan yang dilakukan oleh peranperan dalam teks Keluaran 1-2.

Para ahli pada umumnya menyatakan bahwa narasi Keluaran sebagai bentuk dari kontinuitas janji Tuhan kepada Israel. Jika dilihat dari sistematika narasi Keluaran, peran utamanya selalu berbicara tentang kepemimpinan Musa. Fretheim dengan konstruksi teologinya mengungkapkan sebagai berikut.

Tuhan tidak disebutkan dalam narasi (Keluaran 1:1-19). Manusia-manusia ini bisa saja gagal, dan Tuhan harus menemukan jalan lain menuju masa depan dengan kemungkinan-kemungkinan baru. Hal ini menunjukkan bahwa ada peran penting manusia, meskipun aktivitas Tuhan tampaknya mendominasi narasi. (Terence E. Fretheim, 2014, pp. 596-597).

Hal ini juga didukung oleh Dozeman yang mengungkapkan bahwa tidak adanya Tuhan dalam teks Keluaran 12, memberikan kesempatan untuk melihat penindasan dan kekuasaan dalam perspektif manusia (Dozeman, 2010, p. 56). Dengan dukungan pemahaman ini, dapat memberikan interpretasi dalam narasi Keluaran 1-2 sebagai berikut.

\section{Kepemimpinan Karismatik Raja dalam Keluaran 1:1-14}

1. Tinjauan Teologis Keluaran 1:1-14

(a) Tinjauan teologis ayat 1-7. Menurut Fretheim ayat 7 bukan hanya menerangkan tentang janji dalam sejarah (Abraham) tetapi juga dengan pemenuhan bumi; Poin pentingnya adalah God's 
intentions in creation are being realized in this family... this is microcosmic fulfillment of God's macrocosmic design for the world; saksi dari pekerjaan Tuhan yang terus berlanjut atas penciptaan dan berkat (Terence E. Fretheim, 1991, p. 25). Fretheim menyimpulkan bahwa God's work in creation provides the basis for God's work in redemption; God's work in redemption fullfils God work in creation (Terence E. Fretheim, 1991, p. 26). Sebagai pembanding, adapun Childs melihat bahwa narasi ini sebagai janji kepada leluhur di masa lampau (Childs, 2011, p. 3). Namun sedikit menarik pemahaman Brueggeman yang melihat narasi ini sebagai upaya dari narator untuk proses remembering (Walter Brueggemann, 1994). Langston melihat bahwa narasi dalam keluaran dimulai dengan situasi paradoks.

Kitab Keluaran dimulai dengan perjuangan paradoks antara hidup dan mati. Banyaknya keturunan yang dihasilkan dari janji-janji yang dibuat kepada Abraham (Kej. 13:16; 15:5) kini telah menjadi dasar untuk memusnahkan orang-orang Ibrani. Semakin banyak orang Mesir mencoba mengurangi jumlah mereka, semakin banyak orang Ibrani bertambah. Firaun akhirnya memutuskan pembunuhan semua bayi lakilaki Ibrani, tetapi putrinya sendiri menggagalkan proses tersebut dengan menyelamatkan pemimpin masa depan Ibrani. Kelahiran bangsa Ibrani dimulai dengan kematian. (Scott M. Langston, 2006, p. 13).

(b) Tinjauan teologis ayat 8-14. Fretheim menilai bahwa Keluaran bukanlah deklarasi akan kebebasan, tetapi deklarasi kubergantungan kepada Tuhan (Fretheim 1991, 31). Sebagai pembanding, Durham mengungkapkan bahwa bagian pembukaan dalam kitab Keluaran mengonstruksi kelanjutan dari teologi historis dari leluhur Israel dan menerangkan situasi yang terjadi yang menuju kepada bagian berikutnya yaitu fokus kepada perubahan radikal kepada main-goal dan kelahiran Israel (John I. Durham, 1987, p. 8).

\section{Proses Kepemimpinan Keluaran 1:1-14}

Dalam perspektif teologis, perkembangan penduduk Israel di Mesir dianggap sebagai sebuah 'berkat' atau pemenuhan janji Tuhan kepada Abraham, ataupun secara perspektif kosmis dianggap sebagai pemenuhan mikro-kosmik dalam keluarga. Namun jika dilihat dari proses kepemimpinan, narasi tersebut dimulai dengan Perkembangan penduduk Israel di Mesir Situasi sosial dan politis yang mempengaruhi pengambilan keputusan dari seorang pemimpin (Ay. 7). Raja baru yang tidak mengenal Yusuf dan memerintah tanah Mesir dan merespons pertumbuhan penduduk Israel yang ada di Mesir (Ay. 8). Dituliskan bahwa secara kuantitas penduduk Israel melebihi jumlah penduduk di Mesir. Ada interaksi dari Raja kepada rakyatnya, untuk meyakinkan mereka bahwa permasalahan jumlah 
penduduk itu menjadi masalah yang signifikan (Ay. 9). Respons terhadap situasi tersebut Raja berupaya untuk menghentikan laju pertumbuhan penduduk. Kebijakan tersebut dibumbui oleh isu pembangkangan atau perseteruan yang akan dilakukan oleh kelompok Israel (Ay. 10). Pengawas rodi dikerahkan untuk menindas dengan pekerjaan paksa. Respons dari kelompok Israel berbeda, tidak sesuai dengan rencana awal (Ay. 11). Raja berusaha untuk menghentikan laju pertumbuhan penduduk (menyingkirkan mereka), tetapi justru semakin berkembang (Ay. 12). Informasi ini menyebar kepada seluruh penduduk Mesir sehingga memberikan tekanan yang besar untuk orang Israel ditindas. Ada paradoks antara perspektif teologis dan perspektif kepemimpinan. Pemenuhan penduduk sebagai suatu berkat tetapi di sisi lain memberikan ancaman kepada pemimpin Mesir untuk pemerintahannya. Larrson menilai bahwa tirani sangat sering takut kepada seseorang yang akan mencuri posisinya. Biasanya, akan mempertahankan kekuasaan dengan menindas pihak lain (Larsson, 1999, p. 7).

\section{Nilai-nilai kepemimpinan Keluaran 1:1-} 14

Jika kita melihat teks tersebut dan menilai di dalam proses kepemimpinan, ada beberapa catatan yang dapat diberikan, yaitu: ada gejala charismatic leadership yang dimiliki oleh Raja, hal itu ditunjukkan sebagaimana pengaruh yang sangat besar atas kebijakan yang dibuat oleh pemimpin tersebut dan sedemikian rupa memiliki dampak yang luar biasa besar. Dimulai dengan kerja paksa yang dilakukan oleh pengawas-pengawas rodi yang diperintahkan meluas menjadi kesadaran publik terhadap pandangan negatif warga Mesir terhadap Israel. Dari narasi ini kita dapat melihat karismatik memiliki efektivitas dalam hal pengaruh untuk tujuan tertentu, tetapi juga berbahaya jika disalahgunakan. Tidak ada pertimbangan lebih lanjut yang diterangkan dalam narasi tersebut, permasalahannya hanya pertumbuhan jumlah penduduk ditambah dengan 'penggorengan' isu pemberontakan, menimbulkan penindasan bagi pihak lain.

\section{Creative Disobedience dalam Keluaran 1:15-22}

\section{Tinjauan Teologis Keluaran 1:15-22}

Fretheim mengklaim bahwa kreativitas Tuhan bersifat paralel dengan ketidaktaatan yang cerdik dari bidan-bidan dalam narasi ini (Terence E. Fretheim, 1991, p. 32). Secara teologis, iman daripada bidan-bidan ini berpengaruh bagi Israel (John I. Durham, 1987, p. 13). Fretheim selanjutnya memberikan keterangan bahwa 
Tuhan dituliskan dalam narasi Keluaran 1:20-21, dengan catatan bahwa Tuhan merespons kepada tindakan-tindakan perempuan yang melihat ketidaktaatan dari perintah pemimpin dari bidan-bidan dipandang secara positif (Terence E. Fretheim, 2014, p. 596). Fretheim menerangkan sebagai berikut.

Tuhan bekerja di balik layar melawan situasi yang mengancam ciptaan ini melalui kebijaksanaan dan keberanian lima wanita terpinggirkan. Ketidaktaatan kreatif mereka mempertahankan masa depan bagi Israel dan memungkinkan munculnya pemimpin dalam pribadi Musa. Pengalaman awal hidupnya mewujudkan Israel dan mengantisipasi tindakan ilahi. (Terence E. Fretheim, 1991, p. 23).

\section{Proses Kepemimpinan Keluaran 1:15-22}

Raja memerintahkan kepada bidan yang menolong perempuan-perempuan Ibrani, dengan memberikan perintah langsung membunuh anak laki-laki yang baru lahir (Ay. 15). Bidan-bidan itu disebutkan takut akan Tuhan dan membiarkan bayi-bayi itu hidup (Ay. 16). Ada dua perintah langsung dari Raja mengenai pembunuhan bayi laki-laki dan alasan tidak taat kepada perintah raja (Ay. 16 dan Ay. 18). Ada persetujuan dari Tuhan atas tindakan bidan-bidan tersebut (Ay. 20). Ada pengulangan mengenai pertumbuhan penduduk (1:7 dan 2:20); kontras dengan rencana Raja yang ingin menyingkirkan bangsa Israel karena menganggap sebagai ancaman secara politis (Ay. 20). Melihat upaya pembunuhan masal tidak berhasil, Raja melakukan tindakan secara terbuka dan transparan (mengungkap motif) untuk membuang bayi-bayi tersebut ke dalam sungai Nil (Ay. 22).

\section{Nilai Kepemimpinan Keluaran 1:15-22}

Dari narasi ini dapat dilihat karakteristik dari abuse the power akan selalu memiliki sifat toleransi. Motif pada tahap pertama hanya penindasan, pembunuhan karakter, dan pembunuhan satu keturunan. Namun, narasi ini memberikan keterangan tindakan kepemimpinan yang brilian yang secara teologis oleh Fretheim disebut sebagai creative disobedience. Tindakan kepemimpinan bidan-bidan yang tidak terpengaruh oleh konstruksi sosial ataupun alat dalam mempertahankan kekuasaan seorang Raja, malah berbalik kepada pengungkapan motif dari Raja itu sendiri yang gentar terhadap pemberontakan. Prinsip ini bukanlah suatu legitimasi untuk dapat melakukan tindakan ketidaktaatan, tetapi prinsip yang penting adalah keberanian untuk menilai motif dari perintah pemimpin. Tidak diterangkan apakah bidan-bidan ini mendapatkan hukuman, tetapi pesan dalam ayat 20 secara teologis memberikan kesimpulan bahwa Tuhan menghargai tindakan para bidan-bidan tersebut. 
Pentingnya Tujuan yang Sama dalam Kepemimpinan dalam Keluaran 2:1-10

\section{Tinjauan Teologis Keluaran 2:1-10}

Fretheim mengungkapkan bahwa peristiwa ini merupakan divine irony; Tuhan memakai orang lemah, untuk mempermalukan orang kuat. Tuhan bekerja melalui pribadi yang tidak memiliki kekuatan secara institusional (Terence E. Fretheim, 1991, p. 37). God moves throughout this section in unlikely, and vulnerable ways (Terence E. Fretheim, 1991, p. 38). Selanjutnya, Fretheim menerangkan bahwa perempuanperempuan ini memiliki peran kepemimpinan yang sangat penting. Melawan sistem dominasi dari laki-laki, yang mempertaruhkan nyawanya; dan hasilnya adalah memberikan kesempatan kepada pemimpin Israel yaitu Musa (Terence E. Fretheim, 1991, p. 40).

\section{Proses kepemimpinan}

Orang tua keturunan Lewi memiliki anak laki-laki dan menyembunyikannya selama tiga bulan (Ay. 1-2). Ada peran yang sangat penting dari anak Firaun yang dan hamba-hambanya. Mereka sadar bahwa itu anak orang Ibrani, tetapi berupaya untuk mengangkat anak itu sebagai anaknya (Ay. 10). Ada kompromi antara peran putri Firaun dan ibu bayi tersebut dalam narasi ini. Dengan beberapa kesepakatan untuk menjadi inang penyusu dan mendapatkan upah. Poin utamanya adalah bayi itu selamat (Ay. 9-10).

\section{Nilai kepemimpinan}

Narasi ini menunjukkan kepemimpinan yang efektif. Perempuanperempuan itu menyadari kebijakan Raja; tetapi mereka digerakkan oleh tujuan yang sama yaitu menyelamatkan bayi itu. Para bidan sebagai kaum yang lemah, tetapi justru dapat membuat perubahan yang besar yang memengaruhi seluruh cerita dalam Kitab Keluaran.

\section{The Death of Vision dalam Keluaran 2:11-22}

\section{Tinjauan Teologis Keluaran 2:11-22}

Fretheim mengungkapkan bahwa isu utama dari narasi ini adalah keadilan (Terence E. Fretheim, 1991, p. 44). Durham mengungkapkan bahwa narator memiliki dua tujuan, yaitu: (1) hubungan Musa dengan penderitaan umatnya; pemindahan Musa ke Tanah persiapan terakhirnya untuk pekerjaannya sebagai pembebas, tanah Midian (John I. Durham, 1987).

Cole melihat bahwa, and looked on their burdens means more than 'to see', it means to see with emotion, either satisfaction (Gen. 9:16); or with distress (Gn. 21:16) (Cole, 1973, p. 59). Rosin menerangkan bahwa nama 'gersom' itu 
tidaklah hanya suatu tanda kesedihan saja, melainkan terlebih lagi suatu tanda percaya dan pengharapan (Rosin, 2002, p. 36).

\section{Proses Kepemimpinan Keluaran 2:11-22}

Musa dewasa dan melihat saudarasaudaranya melakukan kerja paksa. Didapati situasi diaman seorang Mesir melakukan kekerasan kepada orang Ibrani (Ay. 11). Musa membunuh orang Mesir itu (Ay. 12). Tindakan Musa yang berupaya untuk menyembunyikan jejak pembunuhannya diketahui oleh pihak lain, bahkan sampai kepada Raja (Ay. 15). Ada upaya pembunuhan Musa oleh raja dengan yang menuntun kepada pelarian Musa ke Midian (Ay. 15). Musa bertemu dengan Rahel dan keramahan dari keluarga imam Midian; dan memiliki seorang anak dengan nama Gersom dengan makna, "Aku telah menjadi seorang pendatang di negeri asing." (Аy. 14-22).

\section{Nilai Kepemimpinan Keluaran 2:11-22}

Menurut Clinton dalam kepemimpinan ada proses the death of vision: di mana Tuhan memproses seorang pemimpin untuk tidak memiliki ambisi pribadi (J. Robert Clinton, 1993, p. 70). Epp menilai bahwa Musa memiliki cukup pelatihan dan pengalaman untuk memiliki kemampuan mengatur banyak orang baik militer ataupun masa; Musa pasti sudah dilatih dengan disiplin dan mengambil keputusan, namun itu tidak cukup (Epp, 1977, p. 32). Hamerling juga menerangkan bahwa Tuhan bekerja memproses pemimpin dengan jangka waktu yang lama, supaya bisa siap untuk mengikuti perintah Tuhan. Sebelum Musa memimpin Israel keluar dari Mesir, Musa pertama-tama harus terasing ke Midian (Hamerling, 2013, p. 55).

\section{Tuhan dan Keberpihakan kepada Orang yang Menderita dalam Keluaran 2:23-25}

\section{Tinjauan Teologis Keluaran 2:23-25}

Fretheim mengungkapkan bahwa waktu yang panjang di Mesir untuk menunggu pekerjaan ilahi yang atas keluaran Israel dari Mesir (Terence E. Fretheim, 1991, p. 47). Brueggeman melihat bahwa dalam narasi ini teridentifikasi ada upaya dari narator untuk melanjutkan kuasa janji Tuhan yang terekspos dalam keadaan tidak berdaya secara sosial yang memberikan penekanan kepada antara janji di masa lampau, dengan pengalaman masa sekarang (Walter Brueggemann, 1994, p. 691). Cole melihat bahwa ini dapat disimpulkan sebagai janji dan penggenapan di mana Tuhan berjanji, mengingat, dan menyelamatkan (Cole, 1973, p. 62). Rosin melihat bahwa 'Tuhan Yang Melihat' itu memandang penting apa yang dilihat-Nya. Ia mengambil tahu tentang orang Israel itu. Ia mengetahui ketidakadilan yang dialami umat-Nya 
dalam perbudakan di Mesir itu (Rosin, 2002, p. 39).

\section{Proses Kepemimpinan Keluaran 2:23-} 25.

Situasi yang berubah dengan kematian seorang Raja (Ay. 23). Ada karakteristik yang berbeda yang ditunjukkan dalam narasi ini yaitu adanya keluhan atas perbudakan (Ay 23). Berbeda dengan pasal 1 dengan penekanan kepada bagaimana mereka masih bisa berkembang di tengah penindasan. Hal ini menunjukkan batas kolektif dari penindasan, sehingga ada pengharapan kolektif dengan tindakan berseru, berteriak minta tolong, dan ditekankan bahwa sampai kepada Tuhan (Ay. 23). Tuhan yang melihat dinamika peran dari seorang raja, perempuanperempuan, dan Musa akhirnya mengambil bagian yang didasarkan atas respons terhadap situasi (Ay. 24). Respons Tuhan terhadap situasi: mendengar keluh kesah mereka, dan mengingat janji kepada Abraham; sebagai hasilnya Tuhan melihat dan memperhatikan (Ay. 23).

\section{Nilai Kepemimpinan Keluaran 2:23-25}

Keberpihakan Tuhan kepada Israel ditunjukkan dengan pemilihan seorang pemimpin (J. Robert Clinton, 1993, p. 65). Ada interaksi antara pemimpin-pengikut yang memberikan prinsip untuk memiliki kesadaran akan tujuan yang sama dengan pemimpinnya. Ide pembebasan Tuhan diproses dengan sebegitu rupa dalam keluaran 1-2 ini, sampai kepada persamaan/ atau kebutuhan dari pengikut untuk dibebaskan. Kesabaran seorang pemimpin untuk 'melihat', 'memperhatikan', dan 'mendengar' atas respons terhadap kesadaran kolektif tentang kerinduan untuk pembebasan. Tuhan tidak bertindak pada saat penindasan yang pertama, tetapi menunggu sampai kepada proses pembentukan Musa untuk menjadi seorang pemimpin. Buber menolong untuk memahami ini dengan menilai bahwa ide pembebasan ini tidak bisa diambil oleh siapa pun baik yang mengalami sebagai seorang budak dan memiliki hubungan dengan budak; tetapi hanya oleh seorang yang telah melalui pengasingan dengan segala hikmat, dan kekuasaan, dan memiliki tindakan yang didasari oleh "goes forth his brethren and observes their burden (Buber, 1946, p. 35).

\section{KESIMPULAN}

Bentuk pemerintahan Teokrasi sering memberikan pemahaman kepada pembaca untuk selalu melihat teks Alkitab, khususnya nilai-nilai kepemimpinan hanya terfokus kepada Tuhan. Namun, teks Keluaran 1-2 merupakan narasi yang menarik, karena tidak ditemukan ada peran Tuhan secara langsung. Analisis kepemimpinan dalam teks Keluaran 1-2 
dengan mempertimbangkan tiga aspek atau prinsip, yakni tinjauan teologis, memerhatikan proses kepemimpinan secara menyeluruh atau tidak fokus pada satu peran tertentu saja, baru refleksi nilai-nilai kepemimpinan dengan melihat juga konsep kepemimpinan umum memberikan deskripsi yang lebih lengkap. Istilah creative disobedience dan death of vision dari kaum minoritas yakni bidan-bidan dan Musa memberikan pemahaman baru tentang pergumulan pemimpin dalam menghadapi persoalan-persoalan kepemimpinan. Refleksi-refleksi kepemimpinan yang didasarkan dengan tiga prinsip di atas, seharusnya dijadikan fondasi untuk membangun kepemimpinan Kristen dalam penelitian-penelitian lanjutan atau dalam ranah praktis.

\section{KONTRIBUSI PENELITIAN}

Artikel ini memberikan kontribusi akademik terhadap teori-teori kepemimpinan, yaitu konsep teologi kepemimpinan Kristen. Adapun tiga kerangka kerja operasional dari konsep tersebut ialah pertama, kesadaran teologis, agensi manusia dalam satu peristiwa, dan integrasi nilai-nilai Kristiani dengan kepemimpinan umum. Dengan demikian, upaya membangun kepemimpinan Kristen memungkinkan tidak hanya didasarkan satu tokoh saja, tetapi dapat melihat satu peristiwa atau proses kepemimpinan secara menyeluruh.

\section{DAFTAR PUSTAKA}

Bekker, C. J. (2009). Towards a Theorical Model of Christian Leadership. Journal of Biblical Perspectives in Leadership, 2(2).

Buber, M. (1946). Moses. East and West Library.

Cenac, J. R. (2010). Leader Emergence and the Phenomenological Work of the Holy Spirit in Acts 2. The Journal of Biblical Perspectives in Leadership, 3(1).

Childs, B. S. (2011). Biblical theology of the Old and New Testaments: theological reflection on the Christian Bible. Augsburg Fortress Publishers.

Cole, R. A. (1973). Exodus: An Introduction and Commentary. Intervarsity Press.

David Noel Freedman. (1992). Moses. In The Anchor Bible Dictionary: $K-N$. Doubleday.

Dozeman, T. B. (2010). Introduction. In T. B. Dozeman (Ed.), Methods for Exodus. Cambridge Univeristy Press.

Epp, T. H. (1977). Moses. Back to the Bible.

Hamerling, J. M. (2013). A Study of the Theology of Leadership in GenesisKings. Southeastern Baptist Theological Seminary.

J. Robert Clinton. (1993). The Bible and Leadership Values: A Book By Book Analysis. Milton Keynes.

John I. Durham. (1987). Word Biblical Commentary Vol. 3, Exodus. Zondervan Academic.

Larsson, G. (1999). Bound for Freedom. Hendrickson Publisher. 
Northouse, P. G. (2016). Leadership: Theory and practice. In SAGE Publications.

https://doi.org/10.1016/s0099-

1333(98)90189-6

Rosin, H. (2002). Kitab Keluaran 1-15. BPK Gunung Mulia.

Scott M. Langston. (2006). Exodus Through the Centuries (Blackwell Bible Commentaries). Blackwell Publisher.

Terence E. Fretheim. (1991). Exodus. John Knox Press.

Terence E. Fretheim. (2014). Issues of Agency in Exodus. In T. B. Dozeman, C. A. Evans, \& J. N. Lohr (Eds.), The Book of Exodus: Composition, Reception, and Interpretation (pp. 591-609). Brill.

Walter Brueggemann. (1994). General And Old Testament Article. In W. Brueggemann, T. E. Fretheim;, W. C. K. Jr., \& L. E. Keck (Eds.), The New Interpreter's Bible: Genesis to Leviticus (Volume 1). Abingdon Press. 